\title{
Genetics of Length of Dormancy Period in Malus Vegetative Buds
}

\author{
Roberto Hauagge ${ }^{1}$ and James N. Cummins \\ Department of Horticultural Sciences, New York State Agricultural Experiment Station, Cornell \\ University, Geneva, NY 14456
}

Additional index words. budbreak, chilling, heat units, heritability, subtropics

\begin{abstract}
In a study of chilling requirement in Malus, broad-sense heritability estimates for the length of vegetative bud dormancy in 43 clones growing under simulated subtropical winter conditions were $0.76 \pm 0.04$ in 1986 and $0.81 \pm 0.04$ in 1987. Narrow-sense heritability estimates were $0.66 \pm 0.13$ in 1986 and $0.69 \pm 0.13$ in 1987. Seedlings with low chilling requirements $(C R)$ were not observed in crosses where both parents had high bud-chilling requirements. 'Koningszuur' did not transmit its long CR to its seedlings. Open-pollinated (OP) seedling populations from the Malus $\times$ domestics Borkh. cultivars Anna, Dorsett Golden, Ein Shemer, Khashabi, Winter Banana, and Zabaoani, and the species and interspecific hybrids M. baccata L. DE\#98, M. brevipes Rehd., M. xrobusta (Carr.) Rehd. DE\#485, M. × robusta No. 5 ('R5'), M. rockii, M. turesi Rehd. PI 34143, and 'Rosedale' had at least $5 \%$ of their descendants in the lower CR classes. In all but one instance, $50 \%$ or more of 'Anna' descendants had low CR. Many of these seedlings were within a few classes of the extreme low CR. It is postulated that the low-CR character present in 'Anna' is controlled by at least one major dominant gene and that minor genes interact to modulate its effects. Very low-CR cultivars have a shallow bud dormancy. This highly heritable component for low bud CR is related to a failure to develop a deep dormancy state, rather than to acceleration of the termination of the dormancy process.
\end{abstract}

In many subtemperate and subtropical regions, winter temperatures are not low enough for long enough to satisfy the CR of temperate-zone apples. Application of chemicals has been necessary to achieve budbreak and cropping. The low-CR apple cultivars now commercially available are lacking in fruit quality. Developing higher-quality, low-chilhng cultivars for subtemperate and subtropical regions requires the hybridization of parents having high quality but high $\mathrm{CR}$ with parents having low CR but low quality. Knowledge of the inheritance pattern of the amount of chilling required to break dormancy is important for developing effective breeding strategies. Heritability $\left(H^{\prime}\right)$ expresses the proportion of the variation of a trait that has a genetic origin. The most important function of heritability is its predictive role, expressing the reliability of the phenotypic value as a guide to breeding value (Falconer, 1981). Parentoffspring regression is the most reliable predictor of response to selection and is probably the most widely used predictor in fruit and nut tree breeding (Hansche, 1983).

Oppenheimer and Slor (1968) presented evidence that the very low chilling character in apple buds is dominant. Small variation for bud $\mathrm{CR}$ is present in crosses involving high-CR parents (Chandler, 1960). Numerous studies on inheritance of bud dormancy in peach have been reported (Lammerts, 1945; Lesley, 1944, 1957; Mowrey and Sherman, 1986; Rodriguez and Sherman, 1985). Results have been variable in small populations of peach in which the CR presumably varied between 400 and 900 chilling units (CU) (Lammerts, 1945; Lesley, 1944, 1957). Narrow-sense heritability ( $\left.H^{\prime}\right)$ has been reported to be consistently high in larger populations requiring $\approx 400 \mathrm{CU}$ (Mowrey and Sherman, 1986; Rodriguez and Sherman, 1985).

Other direct or indirect studies on the inheritance of bud dormancy have not shown a common feature among different taxa,

Received for publication 6 Nov. 1989. We gratefully acknowledge the critical reading and helpful suggestions given by Susan K. Brown and Marvin Pritts. We appreciate the financial aid provided by Purdue Univ. International Programs in Agriculture. The cost of publishing this paper was defrayed in part by the payment of page charges. Under postal regulations, this paper therefore must be hereby marked advertisement solely to indicate this fact.

'Present address: IAPAR-Instituto Agronômico do Paraná, P.O. Box 2301, Curitiba, PR, Brazil 80001. such as Corylus avellana L. (Thompson et al., 1985), Picea abies (L.) Karst (Eriksson et al., 1978), Populus spp. (Pauley and Perry, 1954), Prunus armeniaca L. (Kester et al., 1977), Pyrus spp. (Faust et al., 1976), Rubus spp. (Barrientos and Rodriguez, 1980), and Salix pentandra L. (Juntilla, 1982).

The purpose of this study was to estimate the inheritance of the length of dormancy period in vegetative apple buds by using open- and controlled-pollinated populations that were subjected to "normal" and "mild" simulated winter situations.

\section{Materials and Methods}

Populations from controlled crosses. Stratified apple seeds from 35 controlled crosses were planted in the greenhouse facilities at the New York State Agricultural Experiment Station, Geneva, in early Apr. 1985. These crosses involved the lowchilling 'Anna', 'Dorsett Golden', and 'Ein Shemer'; mediumchilling 'Rosedale', 'Transcendent', and Malus $\times$ robusta DE\#485; high-chilling 'Gala', 'Golden Delicious', and 'Granny Smith'; and very high CR 'Koningszuur' and 'Marin Oufroy' (Hauagge and Cummins, 1991a). Either 30 or 75 seeds per cross were divided into four replicates and planted in 1.5-liter containers that allowed $90 \mathrm{~cm}^{2}$ of soil surface area per plant. Crosses involving 'Anna', 'Ein Shemer', 'Dorsett Golden', and 'Rosedale' had the greater number of plants. At least eight recently grafted plants from each of 43 apple cultivars and species, including the parents used to make the test crosses, were planted under the same conditions on 30 May 1985.

Between 1 and 16 July 1985, when the seedlings had grown to 40 to $60 \mathrm{~cm}$, they were cut back to $5 \mathrm{~cm}$ above the soil surface. One new shoot was allowed to grow per seedling. The prunings were cut into 10 to 15 one-node cuttings; the basal ends were dipped for $5 \mathrm{sec}$ in $1000 \mathrm{ppm}$ 1H-indole-3-butanoic acid (IBA), and the cuttings were rooted in an intermittent mist chamber. Identity of each clone was maintained. All plants were grown in a greenhouse under $16 \mathrm{~h}$ light and were held above a 20C minimum. Hardening and dormancy induction started 110

Abbreviations: $\mathrm{CR}$, chilling requirement; $\mathrm{CU}$, chill unit; GDH, growing degree hours; $\mathrm{H}^{2}$, heritability; $\mathrm{I}_{50}$, index of bud activity; OP, open-pollinated. 
days later by a process modified from Stushnoff (personal communication). Only natural light was supplied after 11 Nov. 1985. Temperature was maintained at $14 \pm 2 \mathrm{C}, 8 \pm 2 \mathrm{C}$, and $14 \pm$ $2 \mathrm{C}$ for 20,40 , and 14 days, respectively. Temperature reached - 4C for $3 \mathrm{~h}$ during two mornings in the 8th week. By this time, $80 \%$ to $95 \%$ of the leaves on all seedlings had dropped or were in an advanced stage of senescence.

Overwintering under alternating-temperature regime. The original seedlings were kept inside the greenhouse after the dormancy induction procedure. They were subjected to an alternating-temperature regime similar to what normally occurs in subtropical areas, where bud dormancy in standard apple cultivars is not completely broken (Hauagge and Cummins, 1991a). We maintained ambient temperature at $5 \pm 2 \mathrm{C}$ for $9 \mathrm{~h}$ at night, then raised it to $14 \pm 3 \mathrm{C}$ during the day. No additional light was supplied. Temperatures as high as $24 \mathrm{C}$ occurred a few times for short periods $(<2 \mathrm{~h})$. After 100 days in 1986 and after 70 days in 1987 , the minimum was raised to $12 \mathrm{C}$ and the maximum to $20 \pm 2 \mathrm{C}$. Accumulation of both CU (Shaltout and Unrath, 1983) and growing degree hours (GDH) (Anderson et al., 1986) began simultaneously when $80 \%$ to $95 \%$ of the leaves abscised or were in an advanced stage of senescence, which occurred at the end of the dormancy induction treatment. GDH accumulated between leaf fall and budbreak (at least one bud reaching greentip stage) under alternating-temperature overwintering conditions is related to $\mathrm{CR}$ determined in subtropical conditions (Hauagge and Cummins, 1991a). Consequently, GDH is an indirect measurement of CR.

Plants were checked every 5th day for budbreak. On 4 Apr. and 2 June 1986, they were evaluated for "degree of adaptation", an index based on the intensity of delayed foliation symptoms shown by the plants after budbreak. Degree of adaptation varied between 0 , the least adapted, and 5, where no symptoms of delayed foliation were observed. The classes were based on the number of buds broken, uniformity of budbreak, and internode elongation. Degree of adaptation is inversely correlated with GDH (Hauagge and Cummins, 1991a). During late May 1986, all plants were cut back to $5 \mathrm{~cm}$ above the soil surface and a similar cycle carried out.

Periodic forcing of rooted cuttings after overwintering at 6 $\pm 1 C$. Rooted cuttings were dug from the original trays during the last phase of the dormancy induction process and packed in groups of 24 in plastic bags with roots in peat-lite mixture. Seven groups of at least 24 rooted cuttings, all from different seedlings in each one of the crosses, were overwintered at $6 \pm$ $1 \mathrm{C}$ and $12 \mathrm{~h}$ light in two growth chambers for 300, 640, 912, 1224, 1560, 2088, and $2592 \mathrm{~h}$. The seedlings in each cross in each chilling treatment were divided in three replicates randomly placed in the growth chambers. Eight grafted plants of each parent received the same treatments. After chilling treatment, plants were forced at $22 \pm 1 \mathrm{C}$ and $16 \mathrm{~h}$ light. Plants were checked every 3rd day for budbreak (at least one bud at the green-tip stage) and were evaluated for degree of adaptation after 21 days. An index of bud activity $\left(I_{50}\right)$ for each progeny was calculated by averaging the $I_{50}$ given for each seedling. The $I_{50}$ value was 50 if budbreak had occurred on the first day of forcing and decreased by 1 for each subsequent day of delay.

$O P$ populations in 1987. OP seeds of 31 apple cultivars and Malus spp. were collected at the experiment station orchards in Geneva. After stratification, 60 seeds from each source were divided into two replicates and planted in the greenhouse on 4 Dec. 1985. Seeds were planted in trays spaced at $6 \times 6 \mathrm{~cm}$, with 0.360 liter of soil per seedling. At least eight grafted plants of each of 16 parents were included in the experiment. Plants in this experiment were 20 to $40 \mathrm{~cm}$ tall at the time of terminal bud formation, compared with 70 to $120 \mathrm{~cm}$ for plants having a soil volume of 1.5 liters. However, terminal buds were better formed and leaf senescence occurred more uniformly during the dormancy induction process.

During Fall 1986, the seedlings were induced into dormancy and overwintered under an alternating-temperature regime, as described previously (Hauagge and Cummins, 1991a).

Heritability estimations. Standard-unit narrow-sense heritability by parent-offspring regression (Frey and Homer, 1957; Hansche, 1983) for the length of bud dormancy was estimated in populations from controlled crosses (1986 and 1987 experiments) and OP populations (1987 experiments).

Broad-sense heritability was calculated for 43 apple cultivars and species representatives with the formula:

$$
\mathrm{H}^{2}=\frac{\mathrm{S}_{\text {cult }}{ }^{2}}{\mathrm{~S}_{\text {cult }}{ }^{2}+\left(\mathrm{S}_{\mathrm{error}}{ }^{2}\right) / \mathrm{r}} \pm \frac{2\left(\mathrm{~S}_{\text {cult }}{ }^{2}\right) /(\mathrm{nc}+2)}{\mathrm{S}_{\text {cult }}{ }^{2}+\left(S_{\text {error }}{ }^{2}\right) / \mathrm{r}}
$$

where $\mathrm{S}_{\text {cult }}{ }^{2}=$ variance among clonally propagated cultivars and species; $\mathrm{S}_{\text {error }}{ }^{2}=$ experimental error; $\mathrm{nc}=$ number of different clones $-1 ; \mathrm{r}=$ number of replications, all estimated from an analysis of variance table.

\section{Results and Discussion}

Alternate-temperature environments. Behavior of 40 apple cultivars and related species overwintered under alternatingtemperature environments has been discussed by us (Hauagge and Cummins, 1991a). Under these conditions, GDH accumulated between leaf fall until budbreak is related to the adaptation of the genotype to subtropical conditions. Only 'Anna', 'Dorsett Golden', and 'Ein Shemer' in both years, and $M$. ×robusta DE\#485, 'Rosedale', and 'Transcendent' in 1987 demonstrated total termination of dormancy and displayed no delayed foliation. Seedling populations from controlled crosses behaved similarly in both years in relation to the length of bud dormancy $(r$ $=0.83$ ). The range between the first and last seedlings and cultivars to break bud was 177 days in both years. This contrasts with the 32-day range observed under field conditions at the experiment station orchards in Geneva.

Broad-sense $\mathrm{H}^{2}$ for the length of bud dormancy in 43 apple clones was estimated to be $0.76 \pm 0.04$ and $0.81 \pm 0.04$ in 1986 and 1987, respectively. These estimates provide information about the maximum possible value of heritability (Hansche, 1983) and indicate the importance of the environment, which contributed to $\approx 20 \%$ of the total variation.

Standard-units heritability (Frey and Homer, 1957) was calculated for seedling populations because seedling age has some effect on length of bud dormancy (Hauagge and Cummins, 1991c); more conservative estimates were obtained with this method. The narrow-sense heritability estimates for the length of bud dormancy in populations from controlled pollination were 0.66 \pm 0.13 in 1986 and $0.69 \pm 0.13$ in 1987 (Figs. 1 and 2; Table 1). Consequently $\mathrm{H}^{2}$ was not improved when seedling age varied from 360 to 560 days. These estimates were generally smaller than those obtained from OP populations (Table 2), which had a much broader genetic constitution. The high narrow-sense estimate for the length of bud dormancy suggests that this trait is controlled largely by additive genetic variance, as are many of the characters examined in deciduous fruit and nut tree species (Hansche, 1983). These estimates are comparable to those observed in low-chilling peach populations (Mowrey and Sher- 


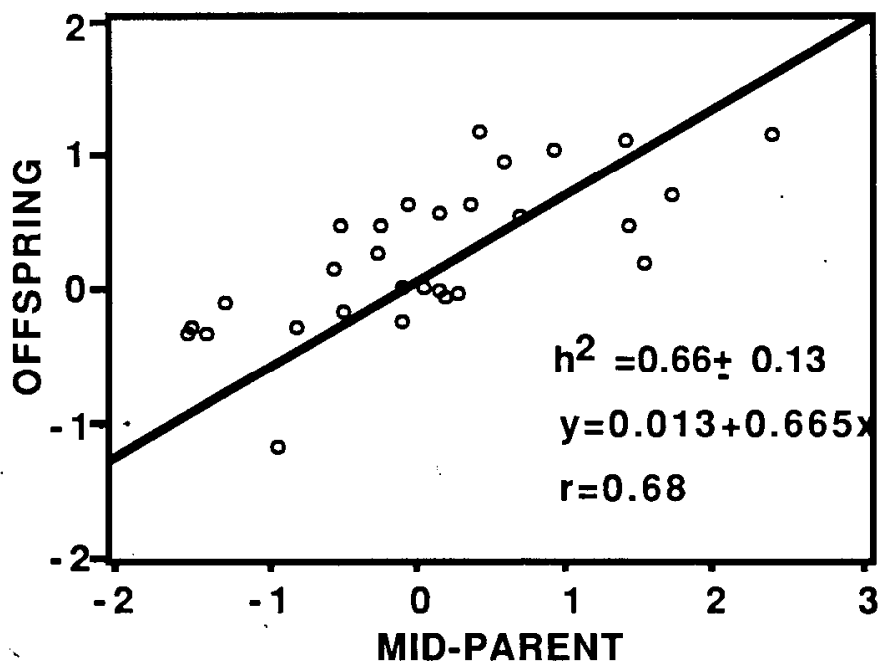

Fig. 1. Regression of offspring on mid-parent for the length of the dormancy period under alternating-temperature regime in 1986. Values are expressed as GDH accumulated from leaf fall until budbreak in standard units.

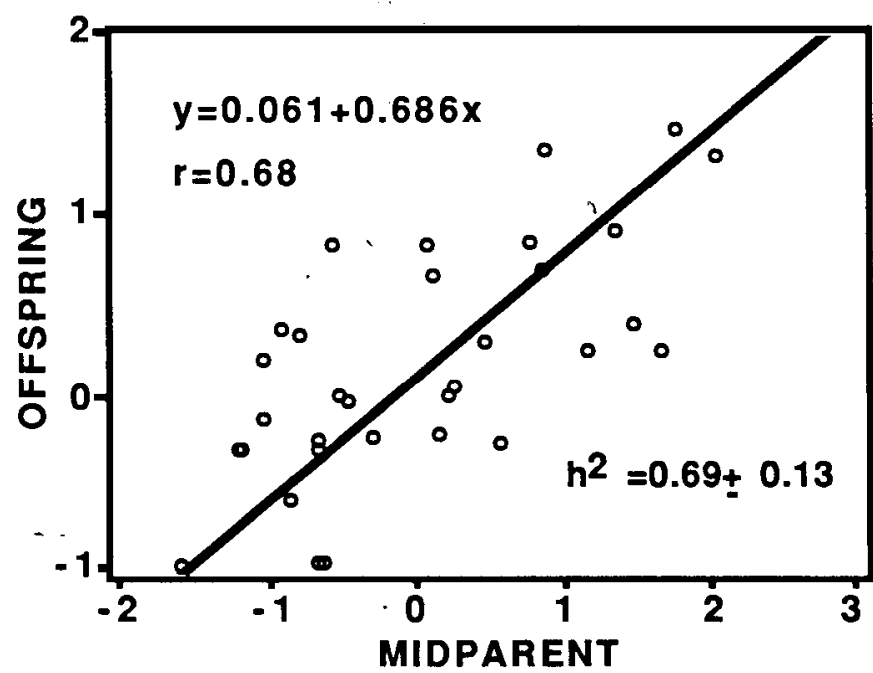

Fig. 2. Regression of offspring on mid-parent for the length of the dormancy period under alternating-temperature regime in 1987. Values are expressed as GDH accumulated from leaf fall unit budbreak in standard units.

man, 1986; Rodriguez and Sherman, 1985). They are probably accurate estimates of the heritability of low bud-chilling requirement in apples, since vegetatively propagated materials under our experimental conditions behaved in a manner very similar to material grown in a mild climate (Hauagge and Cummins, 1991a).

Periodic forcing of rooted cuttings after overwintering at 6 $\pm 1 C$. Although $95 \%$ to $100 \%$ of the seedlings (Fig. 3), as well as grafted parents (data not shown), had abscised their leaves at the time of transplanting, dormancy intensity continued to advance after the chilling treatment had started and before dormancy began to dissipate. It has been observed that $\mathrm{CU}$ requirement under a constant-temperature regime is sometimes higher than when measured under field conditions (Freeman and Martin, 1981; Hauagge and Cummins, 1991a). It is possible that deciduous fruits follow a pattern of development in which dormancy must reach a maximum level before it can be broken by chilling. Consequently, the initial chilling does not contribute
Table 1. GDH accumulation between leaf fall and budbreak of midparents and their progeny under an alternating-temperature regime. GDH is related to CR determined in subtropical conditions (Hauagge and Cummins, 1991a).

\begin{tabular}{|c|c|c|c|c|c|}
\hline \multirow[b]{2}{*}{ Cross $^{2}$} & \multicolumn{2}{|c|}{$\begin{array}{l}\text { Mid-parent } \\
\text { mean GDH } \\
\text { (thousands) }\end{array}$} & \multirow[b]{2}{*}{ No..$^{y}$} & \multicolumn{2}{|c|}{$\begin{array}{c}\text { Progeny mean } \pm \text { sD GDH } \\
\text { (thousands) }\end{array}$} \\
\hline & 1986 & 1987 & & 1986 & 1987 \\
\hline AN OP & 14.4 & 11.9 & 80 & $6.4 \pm 3.5$ & $6.9 \pm 2.5$ \\
\hline $\mathrm{ES} \times \mathrm{AN}$ & -- & 6.9 & 96 & ... & $5.2 \pm 4.0$ \\
\hline $\mathrm{ES} \times \mathrm{DG}$ & $\cdots$ & 7.1 & 96 & --. & $9.0 \pm 4.2$ \\
\hline $\mathrm{ES} \times \mathrm{DG}$ & 7.5 & 7.1 & 94 & $8.9 \pm 4.6$ & $8.9 \pm 3.6$ \\
\hline ES OP & --- & 14.1 & 96 & --- & $9.5 \pm 4.8$ \\
\hline $\mathrm{GA} \times \mathrm{AN}$ & 15.0 & 12.2 & 50 & $6.6 \pm 5.0$ & $8.9 \pm 4.0$ \\
\hline$G A \times D G$ & 15.9 & 12.4 & 51 & $10.7 \pm 4.7$ & $12.1 \pm 5.3$ \\
\hline$G A \times E S$ & 17.3 & 14.5 & 53 & $12.7 \pm 5.4$ & $12.4 \pm 5.5$ \\
\hline $\mathrm{GA} \times \mathrm{KO}^{\circ}$ & 26.9 & 24.5 & 20 & $14.4 \pm 5.9$ & $15.0 \pm 4.3$ \\
\hline $\mathrm{GA} \times \mathrm{MO}$ & 25.6 & 20.6 & 16 & $16.2 \pm 7.4$ & $14.5 \pm 3.5$ \\
\hline$G A \times R S$ & 21.8 & 16.4 & 74 & $15.2 \pm 6.0$ & $13.3 \pm 4.5$ \\
\hline $\mathrm{GA} \times \mathrm{TR}$ & 21.8 & 13.8 & 17 & $13.3 \pm 3.2$ & $9.7 \pm 2.5$ \\
\hline $\mathrm{GD} \times \mathrm{AN}$ & 14.4 & 11.9 & 63 & $7.1 \pm 4.2$ & $8.9 \pm 4.2$ \\
\hline $\mathrm{GD} \times \mathrm{DG}$ & 15.3 & 12.0 & 75 & $12.2 \pm 5.3$ & $13.7 \pm 4.0$ \\
\hline GD $\times \mathrm{ES}$ & 16.7 & 14.1 & 70 & $13.4 \pm 6.0$ & $12.4 \pm 4.4$ \\
\hline$G D \times G A$ & 25.1 & 19.4 & 31 & $15.0 \pm 4.4$ & $14.9 \pm 4.9$ \\
\hline$G D \times G S$ & 18.8 & 16.0 & 19 & $18.7 \pm 2.0$ & $18.0 \pm 4.7$ \\
\hline $\mathrm{GD} \times \mathrm{KO}$ & 26.3 & 24.1 & 19 & $18.1 \pm 4.7$ & $19.5 \pm 5.0$ \\
\hline GD $\times \mathrm{RS}$ & 21.2 & 16.0 & 65 & $18.2 \pm 6.3$ & $16.1 \pm 7.5$ \\
\hline $\mathrm{KO} \times \mathrm{AN}$ & 16.2 & 16.9 & 75 & $7.6 \pm 5.2$ & $7.8 \pm 4.7$ \\
\hline $\mathrm{KO} \times \mathrm{ES}$ & 18.5 & 19.2 & 88 & $10.5 \pm 6.0$ & $12.1 \pm 5.1$ \\
\hline $\mathrm{KO} \times \mathrm{DG}$ & 17.1 & 17.0 & 56 & $13.7 \pm 5.6$ & $17.3 \pm 5.4$ \\
\hline $\mathrm{KO} \times \mathrm{MR}$ & 22.3 & 20.4 & 18 & $14.0 \pm 5.3$ & $9.2 \pm 3.8$ \\
\hline $\mathrm{KO} \times \mathrm{MO}$ & 26.9 & 25.2 & 20 & $22.1 \pm 1.1$ & $18.4 \pm 5.3$ \\
\hline $\mathrm{KO} \times \mathrm{RS}$ & 23.0 & 21.0 & 17 & $19.5 \pm 3.8$ & $16.8 \pm 3.4$ \\
\hline MR $\times$ TR & 17.2 & 9.7 & 18 & $12.2 \pm 3.6$ & $8.2 \pm 1.9$ \\
\hline MR $x$ RS & 17.2 & 12.3 & 18 & $13.3 \pm 7.5$ & $10.3 \pm 1.3$ \\
\hline $\mathrm{MR} \times \mathrm{KO}$ & 22.3 & 20.4 & 21 & $12.5 \pm 3.7$ & $11.8 \pm 3.2$ \\
\hline $\mathrm{MR} \times \mathrm{MO}$ & 21.0 & 16.5 & 22 & $10.7 \pm 2.3$ & $8.4 \pm 4.4$ \\
\hline $\mathrm{MR} \times \mathrm{GA}$ & 21.0 & 15.7 & 18 & $11.8 \pm 6.3$ & $7.4 \pm 1.8$ \\
\hline $\mathrm{MO} \times \mathrm{AN}$ & 13.0 & 13.0 & 17 & $9.5 \pm 6.4$ & $7.5 \pm 4.1$ \\
\hline
\end{tabular}

${ }^{2} \mathrm{AN}=$ 'Anna', ES = 'Ein Shemer', DG = 'Dorsett Golden', GA $=$ 'Gala', GD = 'Golden Delicious', GS = 'Granny Smith', KO = 'Koningszuur', MR = Malus $\times$ robusta $\mathrm{DE}$ \#485, MO = 'Marin Oufroy', RS = 'Rosedale', TR = 'Transcendent', OP = open-pollinated.

${ }^{y}$ No. $=$ number of seedlings in the population.

Table 2. Offspring-parent regression $\mathrm{Hz}$ estimates for the length of dormancy period in OP populations. Length of the dormancy period (CR) of seedling populations was estimated in 1987 under alternating-temperature overwintering by calculating GDH accumulated from leaf fall until budbreak. GDH is related to CR determined in subtropical conditions (Hauagge and Cummins, 1991a). Parents' CR was estimated after periodic field sampling and forcing in 1984-85, 1985-86, and 1986-87 seasons and by GDH accumulation under alternating-temperature overwintering in 1987.

\begin{tabular}{lccc}
\hline \hline Season in which & $\mathrm{H}^{2} \pm \mathrm{SD}$ in & $\begin{array}{c}\text { No. } \\
\text { seedling }\end{array}$ & \\
SR was estimated & $0.87 \pm 0.20$ & 31 & 0.70 \\
\hline $1984-85$ & $0.86 \pm 0.16$ & 31 & 0.76 \\
$1985-86$ & $0.61 \pm 0.17$ & 31 & 0.62 \\
$\begin{array}{l}1986-87 \\
\text { Alternating-temperature } \\
\text { regime, 1987 }\end{array}$ & $0.87 \pm 0.13$ & 16 & 0.86 \\
\hline
\end{tabular}




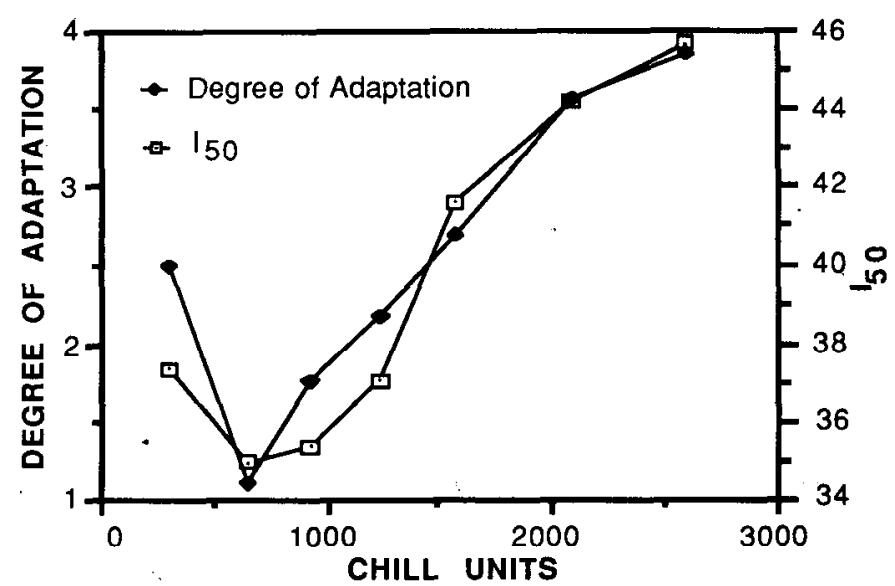

Fig. 3. Degree of adaptation and $I_{50}$ means in 35 apple populations from controlled crosses following a 21-day forcing at $22 \pm 1 \mathrm{C}$ and $16 \mathrm{~h}$ light, after they had been exposed to chilling at $6 \pm 1 \mathrm{C}$ for various periods. Degree of adaptation classes varied between 0, the least adapted, and 5, where no symptoms of delayed foliation were observed. The $I_{50}$ value given for each seedling was 50 if budbreak had occurred in the first day of forcing; it decreased by 1 for each subsequent day's delay.

Table 3. Offspring-mid-parent regression $\mathrm{H}^{2}$ estimates for degree of adaptation in 35 cross-pollinated apple families after chilling at 6.0 $\pm 1 \mathrm{C}$ for various periods. Degree of adaptation is an index based on the intensity of delayed foliation symptoms shown by the plants after forcing $(0=$ least adapted and $5=$ no symptoms of delayed foliation).

\begin{tabular}{ccc}
\hline \hline $\begin{array}{c}\text { Chilling hours } \\
\text { at } 6 \pm 1 \mathrm{C}\end{array}$ & $\begin{array}{c}\mathrm{H}^{2} \pm \mathrm{SD} \text { in } \\
\text { standard units }\end{array}$ & $r$ \\
\hline 300 & $0.47 \pm 0.12$ & 0.61 \\
640 & $0.37 \pm 0.14$ & 0.47 \\
912 & $0.34 \pm 0.16$ & 0.37 \\
1224 & $0.63 \pm 0.15$ & 0.62 \\
1560 & $0.65 \pm 0.12$ & 0.72 \\
-2088 & $0.43 \pm 0.10$ & 0.64 \\
2592 & $0.53 \pm 0.42$ & 0.70 \\
\hline
\end{tabular}

much to the breaking of dormancy because the buds are not fully dormant. This situation may explain why mid- and latewinter chilling is sometimes more effective than early chilling under subtropical conditions.

Inheritance of CR measured by the degree of adaptation was higher in the 1224 and $1560 \mathrm{CU}$ treatments than in any others (Table 3), which corresponded to $\approx 600$ and $900 \mathrm{CU}$ accumulated after the deepest dormancy had been observed. In this way, the higher selection efficiency could be achieved under these circumstances. However, the lower and more variable value for $\mathrm{H}^{2}$, the difficulty in determining the deepest dormancy, and the amount of work required make this method less practical for selection than overwintering the seedlings under an alternatingtemperature regime. In addition, the continuous chilling treatment may not reflect the real situation under chilling-deficient climates. This assumption is suggested by the correlation coefficients between the lengths of bud dormancy of the same seedlings estimated under different overwintering conditions. These correlation coefficients were smaller for comparisons between the same populations under "subtropical" and "uniform winter" conditions $(-0.71 * * *$ for 1986 and $-0.65 * * *$ for 1987) than for different estimations under a subtropical environment $(+0.81 * * *)$. Differences in the CR determined under cold vs. subtropical winters were also found in mature apple clones (Hauagge and Cummins, 1991a).

Population frequency distribution for the length of dormancy period. In breeding deciduous fruit tree species and interpreting the results of inheritance studies, one must take into consideration the special features of these species as fruit crops and the character in consideration.

First, apple is propagated vegetatively, and all genetic components of variance are important. Second, in mild climates, budbreak timing is closely related to the bud CR (Hauagge and Cummins, 1991a; Miller and Baker, 1982; Oppenheimer, 1962; Oppenheimer and Slor, 1968). Therefore, specific gene combinations are needed to fit specific environmental conditions, rather than simply the accumulation of favorable genes in the population. If budbreak is too early, the risk of frost damage is increased, yet an excessively high bud CR will increase the probability that the $\mathrm{CR}$ will not be fully satisfied. Third, since apple seedlings have a long juvenile period (4-10 years), there is an urgent need to incorporate important traits early in the program.

'Anna' and 'Ein Shemer' are thought to be hybrids between low-CR parents and 'Golden Delicious' (Brooks and Olmo, 1972). 'Anna', closely followed by 'Dorsett Golden' and then 'Ein Shemer', has some of the lowest bud CR found in $M . \times d o-$ mestics, and these clones have the higher fruit quality within this group. Nonetheless, they do not have the same genotypic value in relation to the $C R$ means of their descendants, which was uniform when tested in three different female parents (Table 4). In addition, although 'Koningszuur', one of the female parents, has a very long dormancy period, it does not markedly transmit this characteristic to its seedlings.

The frequency distribution of the logarithm of GDH, accumulated between leaf fall until budbreak under an alternatingtemperature regime for seedlings in controlled crosses with 'Gala', 'Golden Delicious', and 'Koningszuur' as female parents and seedlings from OP populations of these cultivars, is shown in Figs. 4 and 5. Parents and seedlings should not be compared directly (Hauagge and Cummins, 1991c) because juvenility factors may affect dormancy. Therefore, the classes of seedlings that were unique to crosses involving at least one low or intermediate CR parent were shaded in solid black, when compared with seedlings in crosses where both parents had high $\mathrm{CR}$, such as crosses involving 'Gala', 'Golden Delicious', 'Granny Smith', 'Koningszuur', 'Marin Oufroy', and many OP families (Figs. 4 and 5). Seedlings with lower CR were not observed in crosses where both parents had high bud CR.

Table 4. Mean bud dormancy length as expressed by GDH accumulated from leaf fall until budbreak in hybrid progenies involving 'Gala', 'Golden Delicious', and 'Koningszuur' as seed parents and 'Anna', 'Dorsett Golden', and 'Ein Shemer' as pollen parents. (No significant differences were found among the female parents.)

\begin{tabular}{lc}
\hline \hline Parent & $\begin{array}{c}\text { GDH } \\
\text { (thousands) }\end{array}$ \\
\hline Female & 10.6 \\
$\quad$ Gala & 11.0 \\
Golden Delicious & 11.8 \\
Koningszuur & $7.7 \mathrm{a}^{\mathbf{z}}$ \\
Male & $12.6 \mathrm{~b}$ \\
Anna & $12.9 \mathrm{~b}$ \\
Dorsett Golden & \\
Ein Shemer & \\
${ }^{2}$ Mean separation in the column by Duncan's multiple range test, $\boldsymbol{P}=$ \\
0.05.
\end{tabular}




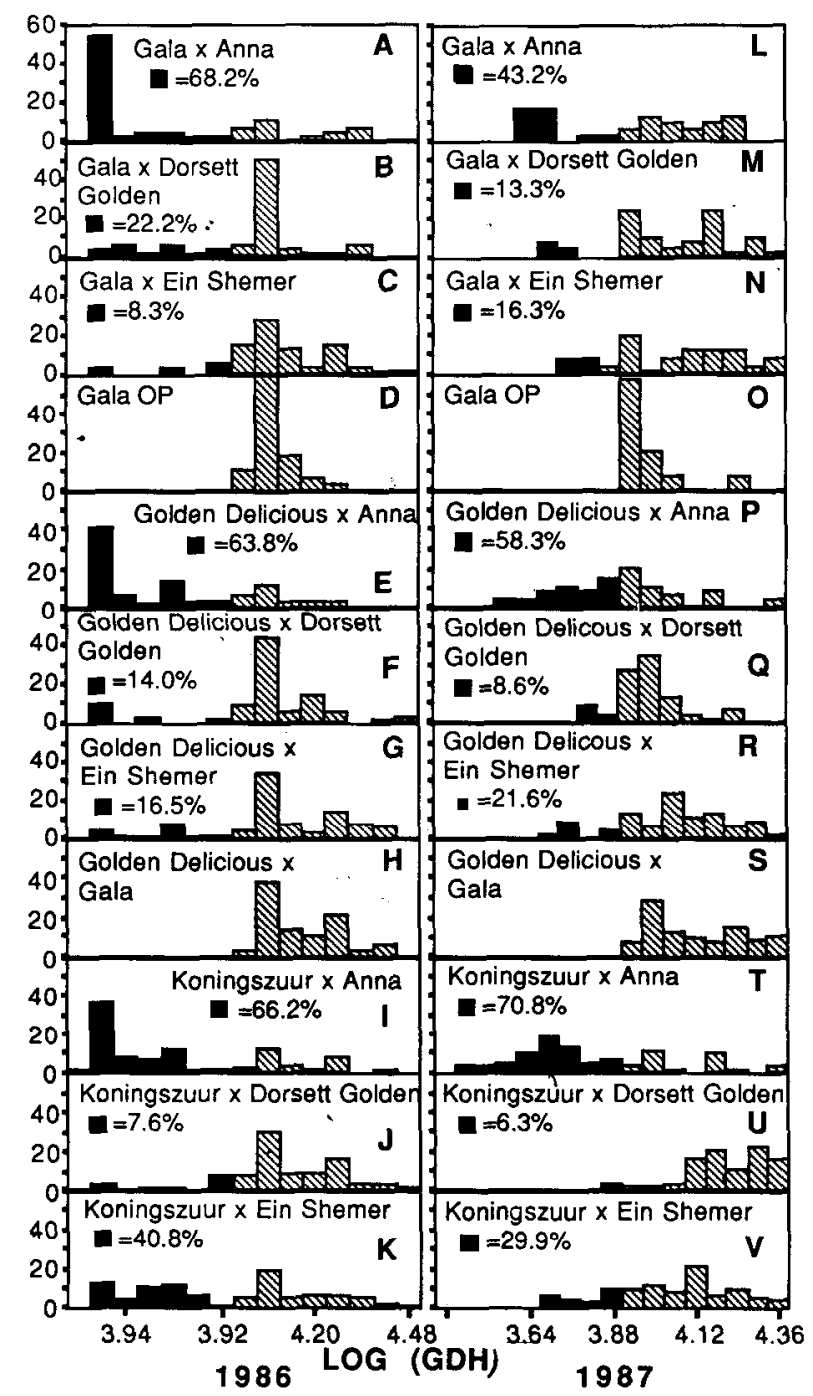

Fig. 4. Frequency distribution of the logarithm of GDH accumulated from leaf fall until budbreak in progenies having 'Gala', 'Golden Delicious', and 'Koningszuur' as the female parent. Classes in solid black are unique to crosses involving a low bud CR parent. Seedlings were overwintered under an alternating-temperature regime in 1986 and 1987. GDH is related to CR determined in subtropical conditions (Hauagge and Cummins, 1991a).

The patterns of distribution of 'Anna', 'Dorsett Golden', and 'Ein Shemer' seedlings into low-CR classes were uniform for each of the low-CR parents in both years. Among 'Anna' seedlings, $64 \%$ to $68 \%$ were low CR in 1986 and $43 \%$ to $71 \%$ in 1987. Progenies of 'Dorsett Golden' and 'Ein Shemer' ranked lower in both years (Fig. 4). In the 1987 experiments, crosses between 'Ein Shemer' and 'Anna' and between 'Ein Shemer' and 'Dorsett Golden', $72.3 \%$ and 51.8910 of seedlings, respectively, were in the low-CR classes (data not shown). Many of these seedlings were within a few classes of the extreme low CR. Differences were less clear in the 1987 experiments, in which $\mathrm{CU}$ accumulation was more rapid and completed more quickly. Distinction between CR classes is less clear in colder winters (Oppenheimer and Slor, 1968). A concentration of seedlings in the middle classes and an accentuated decrease in the frequency of both extremes should be observed if the low CR character were only the result of the action of additive genes. We did not observe this, especially when 'Anna' was one of the parents. Consequently, we postulate that the low CR char-

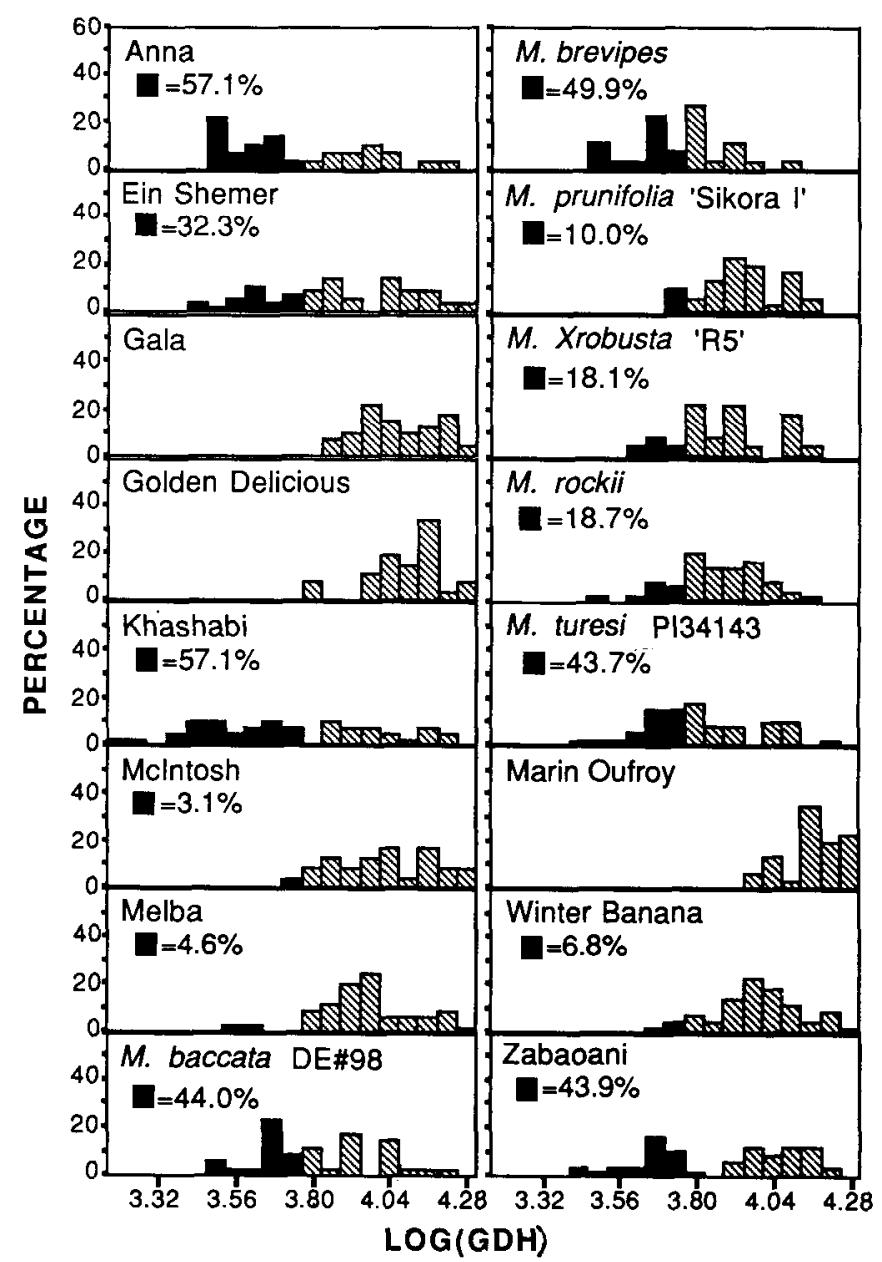

Fig. 5. Frequency distribution of the logarithm of GDH accumulated from leaf fall until budbreak in OP apple seedling populations. Classes in solid black are unique to populations in which the female parent had low bud CR. Seedlings were overwintered under an alternatingtemperature regime. GDH is related to $\mathrm{CR}$ determined in subtropical conditions (Hauagge and Cummins, 1991a).

acter present in 'Anna' is caused by at least one major dominant gene and that minor genes interact to modulate this effect in different classes.

Study of the inheritance of seed or bud dormancy is complicated by factors such as the nonqualitative nature of the dormancy process, as well as the multiple range of factors that affect the phenomenon. Probably any gene that would affect branching pattern, onset of dormancy, temperature efficiency for breaking dormancy, or chilling negation would modify the length of the dormancy period or the action of the genes that could be directly involved in dormancy. Nonetheless, highly heritable components of low CR, which caused marked shifts in the resulting population, were observed in this study. Somatic mutants, which delayed budbreak in almond (Kester et al., 1977) and improved budbreak in apple under mild winter conditions (Aguilar, 1979), peach (Lesley, 1944), and pear (Lecrenier, 1972), have been reported. The extent of the changes, however, has not been closely monitored. Probably only a few loci are involved in these cases, since not many loci are expected to mutate at the same time. 'Khashabi', and perhaps 'Ein Shemer' and 'Zabaoani' (Fig. 5), may fall in a similar category. The assumption of few loci strongly supports previous observations by Oppenheimer and Slor (1968). A single recessive gene for 
nondormancy was found in Corylus avellana L. (Thompson et al., 1985).

'Anna' is self-incompatible (Crocker et al., 1979), and our 'Anna' OP seedling populations came almost entirely from crosses with standard (high-CR) apple cultivars in the experiment station orchard. The OP seedling populations from 'Anna', 'Dorsett Golden', 'Ein Shemer', 'Khashabi', 'Winter Banana', 'Zabaoani', and the species of interspecific hybrids M. baccata DE\#98, M. brevipes, $M$. × robusta 'R5', M. rockii, and $M$. turesi PI 34143 (Fig. 5), and M. × robusta DE\#485 and 'Rosedale' (data not shown) had at least $5 \%$ of their descendants in these 'lower CR classes, with distribution sometimes approaching normal. 'Liberty' and 'Early McIntosh' OP populations exhibited $2.3 \%$ and $2.5 \%$, respectively, of seedlings with a lower CR than standard apple cultivars. The frequency distribution for the length of dormancy period of 'Beverly Hills', 'Delicious', 'Governor Carr', 'Hume', 'King Cole', 'Leyda', 'Northern Spy', 'Nova Easygro', NY 615, and 'Priscilla' all resemble 'Gala' and 'Golden Delicious' (Fig. 5), with no seedlings in the lower CR classes.

Very low-CR cultivars have a very shallow dormancy (Hauagge and Cummins, 1991 b). Many seedlings that had one very lowCR parent had their buds broken normally after dormancy induction treatment and before chilling was applied. Propagules of the same seedling showed similar behavior (data not shown). It appears, therefore, that this highly inheritable component for low CR is related to failure to develop a deep dormancy state, rather than to an acceleration of the termination of the dormancy process.

Rapid genetic progress toward the goal of high-quality, lowCR apple cultivars can be expected from mating 'Anna' with high-quality, high-CR cultivars. 'Dorsett Golden' and 'Ein Shemer' can also be used, but considerably larger numbers of seedlings will be required to accomplish similar progress, if very low CR is needed. Mating these low-chilling cultivars with highchilling, higher quality introductions, such as 'Liberty' and 'Jonafree', that are also resistant to disease should produce lowchilling, disease-resistant, higher quality apples than are available today. This procedure could revolutionize apple production in subtemperate and subtropical regions.

\section{Literature Cited}

Aguilar, A.L. 1979. Fenologia de mutantes de manzano de bajo requerimiento de frio. Proc. Trop. Reg. Amer. Soc. Hort. Sci. 23:3033.

Anderson, J. L., E.A. Richardson, and C.K. Kesner. 1986. Validation of chill unit and flower bud phenology models for 'Montmorency' sour cherry. Acts Hort. 184:71-78.

Barrientos, F.P. and J. Rodriguez-A. 1980. Transgressive segregation for winter chilling requirement in the red raspberry cultivar Mailing Exploit. Acts Hort. 112:21-24.

Brooks, R.M. and H.P. Olmo. 1972. Register of new fruit and nut varieties. Univ. of California Press, Berkeley.

Chandler, W.H. 1960. Some studies of rest in apple trees. Proc. Amer. Soc. Hort. Sci. 76:1-9.

Crocker, T. E., W.B. Sherman, and R.J. Knight, Jr. 1979. Self-unfruitfulness of 'Anna' apple. Fruit Var. J. 33:65-66.

Eriksson, G., I. Ekberg, I. Dormling, B. Matérn, and D. von Wett- stein. 1978. Inheritance of bud-set and bud-flushing in Picea abies (L.) Karst. Theor. Applied Genet. 52:3-19.

Falconer, D.S. 1981. Introduction to quantitative genetics. Longman, London.

Faust, M., R. Zimmerman, and T. van der Zwet. 1976. Genetic transmission of bloom date in pears. HortScience $11: 59-60$.

Freeman, M.W. and G.C. Martin. 1981. Peach floral budbreak and abscisic acid content as affected by mist, light, and temperature treatments during rest. J. Amer. Soc. Hort. Sci. 106:333-336.

Frey, J.K. and T. Homer. 1957. Heritability in standard units. Agron. J. 49:59-62.

Hansche, P.E. 1983. Response to selection, p. 154. In: J.N. Moore and J. Janick (eds. ). Methods in fruit breeding. Purdue Univ. Press, West Lafayette, Ind.

Hauagge, R. and J.N. Cummins. 1991a. Phenotypic variation of the length of bud dormancy in apple cultivars and related Malus species. J. Amer. Soc. Hort. Sci. 116:100-106.

Hauagge, R. and J.N. Cummins. 1991b. Seasonal variation in intensity of bud dormancy in apple cultivars and related Malus species. J. Amer. Soc. Hort. Sci. 116:107-115.

Hauagge, R. and J.N. Cummins. 1991c. Age, growing temperatures, and growth retardants influence induction and length of dormancy in Malus. J. Amer. Soc. Hort. Sci 116:116-120.

Juntilla, O. 1982. The cessation of apical growth in latitudinal ecotypes and ecotype crosses of Salk pentandra L. J. Expt. Bet. 33:10211029.

Kester, D. E., P. Raddi, and R. Asay. 1977. Correlations of chilling requirements for germination, blooming and leafing within and among seedling populations of almond. J. Amer. Soc. Hort. Sci. 102:145148.

Lammerts, W.E. 1945. The breeding of ornamental edible peaches for mild climates. I. Inheritance of tree and flower characters. Amer. J. Bet. 32:53-61.

Lecrenier, A. 1972. Situation des arbres fruitiers a pépins en Algérie. 1ére partie. Projet Algérie 30. Formation professionelle. FAO, Rome, Italy.

Lesley, J.W. 1944. Peach breeding in relation to winter chilling requirement. Proc. Amer. Soc. Hort. Sci. 45:243-250.

Lesley, L.W. 1957. A genetic study of inbreeding and of crossing inbred lines of peaches. Proc. Amer. Soc. Hort. Sci. 70:93-103.

Miller, E.P. and L.H. Baker. 1982. An evaluation of apple cultivars for Central and North Florida. Proc. Fla. State Hort. Soc. 95:8890.

Mowrey, B.D. and W.B. Sherman. 1986. Relationship between autumn growth cessation and chilling requirement in peach. Fruit Var. J. 40:24-28.

Oppenheimer, C.H. 1982. Breeding of apples for a subtropical climate. Proc. 16th Intl. Hort. Congr., Brussels. 3: 18-24.

Oppenheimer, C.H. and E. Slor. 1968. Breeding apples for subtropical climate II. Analysis of two F2 and nine backcross populations. Theor. Applied Genet. 38:97-102.

Pauley, S.S. and T.O. Perry. 1954. Ecotypic variation of the photoperiodic response in Populus. J. Arnold Arb. 35:167-187.

Rodriguez-A., J. and W.B. Sherman. 1985. Relationships between parental, seed, and seedling chilling requirement in peach and nectarine. J. Amer. Soc. Hort. Sci. 110:627-630.

Shaltout, A.D. and C.R. Unrath. 1983. Rest completion prediction model for 'Starkrimson Delicious' apples. J. Amer. Soc. Hort. Sci. 108:957-961.

Thompson, M. M., D.C. Smith, and J.E. Burgess. 1985. Nondormant mutants in a temperate tree species, Corylus avellana L. Theor. Applied Genet. 70:687-692. 